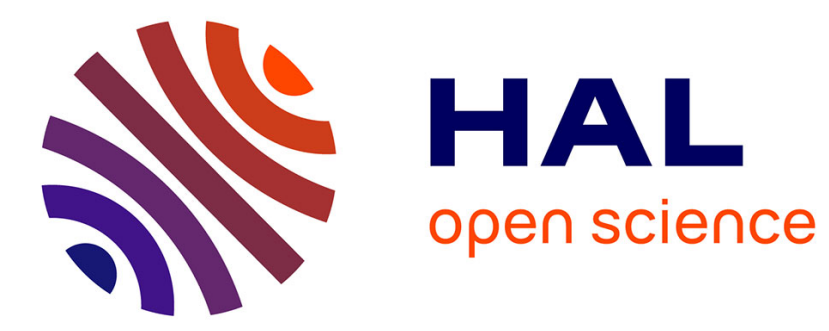

\title{
Diasporic Identity, Transnational Agency, and the Neoliberal Reconfiguration of Global Migration
}

Thomas Lacroix

\section{To cite this version:}

Thomas Lacroix. Diasporic Identity, Transnational Agency, and the Neoliberal Reconfiguration of Global Migration. Diaspora, 2013, 2007-16 (3), pp.401-415. 10.1353/dsp.2007.0020 . halshs00819880

\section{HAL Id: halshs-00819880 \\ https://shs.hal.science/halshs-00819880}

Submitted on 10 Apr 2021

HAL is a multi-disciplinary open access archive for the deposit and dissemination of scientific research documents, whether they are published or not. The documents may come from teaching and research institutions in France or abroad, or from public or private research centers.
L'archive ouverte pluridisciplinaire HAL, est destinée au dépôt et à la diffusion de documents scientifiques de niveau recherche, publiés ou non, émanant des établissements d'enseignement et de recherche français ou étrangers, des laboratoires publics ou privés. 
Thomas Lacroix, "Diasporic Identity, Transnational Agency, and the Neoliberal Reconfiguration of Global Migration," Diaspora 16, 3 (2007): •.•_.•. ( ) 2013 Diaspora: a journal of transnational studies.

\title{
Diasporic Identity, Transnational Agency, and the Neoliberal Reconfiguration of Global Migration
}

\author{
Thomas Lacroix
}

University of Poitiers and International Migration Institute, University of Oxford

\begin{abstract}
Diaspora and Transnationalism: Concepts, Theories and Methods. Eds. Rainer Bauböck and Thomas Faist. Amsterdam: University Press of Amsterdam, IMISCOE Research series, 2010.
\end{abstract}

Key words: Diaspora, transnationalism, globality, methodological nationalism, neorealism

This book is the latest step in the long-standing dialogue between two academic fields:

transnational studies and diaspora studies. These share a common initial intent: the will to place migrants' experience at the core of migration studies, rather than on the integration of migrants into the new host society or the development of origin societies. However, the two endeavors also differ. Scholars of diaspora have focused on the processes through which migrants maintain a shared identity despite their dispersion and its consequences for integration and state politics. In contrast, transnationalists focus on micro-level practices and networks forged by migrants across state borders without necessarily presuming a shared sense of belonging. Recently, the two fields of study have followed converging paths. Works on diasporas have increasingly 
incorporated micro-level activities in their analysis while, conversely, research on transnationalism has paid growing attention to the importance of macro-level dynamics and actors such as states. In 1999, Robin Cohen and Steven Vertovec's book and in particular their landmark "Introduction" heralded this convergence. Since then, diasporic groups are commonly perceived as a specific category of transnational formation. Admittedly, diasporas differ from other transnational communities, owing to an enduring group consciousness forged through cross-borders ties and practices. Although Diaspora and Transnationalism endorses this view, it also reveals new perspectives on the scholarship not only in the two related fields, but others as well. Indeed, since the early 2000s, the concepts of diaspora and (to a lesser extent) transnationalism have permeated the vocabulary of policy makers. The growing number of diasporic policies formulated by states and intended to attract the economic favor of their expatriate groups has led some academics to revisit common assumptions and theories about the making of transnational and diaspora groups. In consequence, new theoretical stances have emerged. Diaspora and Transnationalism reflects the current re-composition of the academic debate.

The book is divided into three sections that explore the theoretical, conceptual, and methodological frameworks of the two approaches. This opus is an effort to shed new light on diaspora and transnationalism by redrawing the margins that separate and juxtapose them. The project that underpins this work is one of redefinition, of pointing to the content of the concepts at issue and exploring possible combinations. At first sight, no common ground emerges from this collection of papers. In many regards, this book appears as a series of monologues on diaspora, transnationalism, and sometimes (but not always) their relationships. The aim of the book is not to weave together an overarching theory. Nevertheless, its merit is to provide a 
panoramic view of the variety of themes, perspectives, and methods through which the relationship of diaspora and transnationalism is currently addressed by students of migration.

In the first place, the book illustrates the convergence between the two fields, which is partially related to the growing politicization of the notion of diaspora. In an attempt to provide a theoretical justification for this convergence, Thomas Faist argues that diaspora and transnational studies share the same epistemological terrain, one that lies between methodological nationalism and globalization studies. In addition, several other articles (by Valentina Mazzucato, Koen Jonkers, Kathrin Kissau, Uwe Hunger, Laura Morales, and Laia Jorba) show how recent methodological innovations have provided common methodological tools for the study of diasporas and transnational phenomena. But, in the second place, Diaspora and Transnationalism reflects persistent past and recent academic quibbles. Several contributions make the case that contemporary diaspora formations are an outcome of state efforts to engage with their nationals living abroad. In contrast, transnationalism appears as a grassroots process that escapes from state control (see Rainer Bauböck). In this respect, the book is strongly marked by a recent neorealist turn in migration studies (that will be discussed later; it illustrates the current re-evaluation of the role of the state in the formation of cross-border social entities. In this essay, I will successively present the two opposite trends that characterize contemporary debate on diaspora and transnationalism: one characterized by convergence that is demonstrably present in some areas, but also another trend of persistent divergence between certain academic stances.

\section{Theoretical, Epistemological, and Methodological Convergences}




\subsection{Diaspora and Transnationalism as Two Facets of the Same Coin: From Utilitarian to Scholarly Discourses}

In the 2000s, the terms diaspora and transnationalism crossed the border that usually separates the scholarly-academic and policy worlds; this crossing was accompanied by the conceptual distortions such moves frequently involve. The chapters by Weinar, Koinova, and Waterbury explore the use of these terms by public officials and civil society actors. This use is primarily driven by utilitarian considerations. For Waterbury, states develop diasporic policies either to support development plans, muster political support, or to reassert a national myth (136). Migrants' remittances are becoming the new "mantra" of development stakeholders (Kapur 2004). For example, the African Union defines the African diaspora as the "peoples of African origin living outside the continent, irrespective of their citizenship and nationality and who are willing to contribute to the development of the continent and the building of the African Union” (Waterbury 79). Myra Waterbury fills a gap in the literature on diaspora engagement policies by documenting "kin state policies." These policies target still-territorialized populations that found themselves in a foreign country not because they moved but in the wake of border redefinitions after World War I. Interestingly, the term diaspora is also used to name these populations in Eastern European countries. This use is underpinned by political strategies. For example, in Serbia, discourses about the diaspora justify irredentist and nationalistic ambitions. The Serbian Unity Congress, which acted as the official representative of US-based Serbians, has provided constant support to nationalist parties in Serbia during the nineties (Koinova, 159). Maria Koinova (chapter 8) shows how the term is instrumentalized to enable the diaspora to 
pursue a political agenda in the origin country. The chapter unravels the underpinnings of such discourses and shows how, behind the promotion of democratic values and procedures, diaspora groups strive to achieve particularistic political aims in their land of origin.

The thriving literature produced by international, state, and civil society organizations on the matter pays little regard to the definitional criteria usually deployed by academics, such as "spatial dissemination, collective identity, integration, intensity of mobility," and so forth. Furthermore, the political use of diaspora and transnationalism does not establish any conceptual distinction between the terms. It is true that transnationalism and its lexical field are far less present in this politicization literature. However, when it is present, it is generally used to qualify the cross-border networks and practices of diaspora groups. In this perspective, the two terms are used to shed light on two facets of the same phenomenon. While diaspora designates a group sharing a political identity, transnationalism is used to refer to the actual practices of migrants. The two concepts are a lens focused on the same object, namely, the cross-border socialities produced by migration. The difference between the two words is of focus, not of nature.

If academic definitions, as argued by Weinar, have never really informed stakeholders' discourses, the contrary is certainly less true. The author notes the recent enlargement of scholarly definition of the concept of diaspora. For example, Van Hear, Vertovec, and Pieke $(2004,3)$ see diasporas as people on the move with multifarious linkages maintained with the homeland. In this context, Weinar is right to state that "this formulation makes diasporas hardly distinguishable from a transnational view on migrant communities" (76).

Against this backdrop, the introductory chapter of Thomas Faist appears as an attempt to ground the correspondence between the two concepts into a rigorous epistemological framework. Due to the nature of their object, the study of diaspora and transnationalism can be seen as 
critiques of methodological nationalism and global studies. The latter, although standing at two opposite scales of the sociological spectrum, tend to convey a homogenized (not to say essentialist) portrait of social life, be it territorially bounded within state borders (for methodological nationalists) or utterly deterritorialized (for scholars of globalization). The concepts of diaspora and transnationalism represent a response to uni-scalar approaches. They assert the multi-polarity of social processes beyond state borders while each "pole" remains firmly rooted in local settings. What makes these socialities distinctive compared to non-migrant ones, beyond their cross-border dimension, is their dialectic nature. In effect, diaspora and transnational communities are social entities forged between distant origins and localized settlement, between sameness and otherness, mobility and sedentarity, locality and globality. As put forward by Thomas Faist (16), diasporas and transnationalism are two "glocal" phenomena." Arguably, transnationalism and diaspora are two approaches that thrive on an epistemological territory bounded by "nationally focused" studies on the one hand and by "global studies" on the other (14-6). Indeed, "methodological nationalism" has been the target of transnational and diaspora experts for nearly a decade now (Wimmer and Glick Schiller 2003). Transnational studies, deeply infused with behaviorism since the onset, are particularly reactive to any form of essentialism and methodological nationalism. The latter is accused of conveying an essentialist conception of society whose limits would be "naturally" congruent with the state's. Peggy Levitt and Nina Glick Schiller (2004) identify three forms of methodological nationalism: (1) ignoring or disregarding nations as a political and social construct; (2) taking for granted that the boundaries of the nation-state define the unit of analysis; (3) restricting the study of social processes to the political and geographic boundaries of a particular nation-state. The 
study of migrants engaged in maintaining cross-border practices and social ties challenges the conception of society as a strictly bounded and self-sufficient arena.

Whether the battle against methodological nationalism can be won is another matter. In a context where statistics are produced by national institutions, the quantitative picture of the world is still almost exclusively focused on nation-states. Furthermore, there is a growing acknowledgment that states and territorially bounded institutions such as political parties, religious organizations, village communities, and so forth do play a role in the formation of diasporas and transnational phenomena. In fact, migrants do not always challenge - they often also reproduce and utilize — an array of societal hegemonies (whether racial, gender, ideological, or class hegemonies) in the transnational space. There is therefore an implicit acknowledgment that bounded societies do matter as a unit of production of globalized hegemonies. Dismissing (disqualifying?) the concept of society (Touraine 2007) under the dubious assumption that it colludes with a statist ideology would deprive us of the opportunity of analyzing the production of major social patterns and their transposition into migrant social groups. Furthermore, as mentioned earlier, there is an ongoing reassessment of the role of the state in cross-border social processes. States and societies continue to remain prevailing structural forces of social processes. In a similar vein, Thomas Faist emphasizes the discrepancies between global and migration studies. For Faist, the literature on migrant cross-border exchanges and socialities offers little comfort to those who hope for and advocate or claim to see the emergence of a global consciousness, or a global normative framework that is linked to the promotion of "postnational" human rights (Soysal 1994). "Diaspora and transnational concepts, in contrast to global and world theory concepts, often start from the observation that, while there is less of a 
requirement of physical and geographical proximity for social life, there is still no clear tendency towards universalisation" (15).

However, the relationship between diaspora and transnational studies, on the one hand, and global studies on the other, is far less confrontational. Although arguably distinct, these academic fields stem from the same historical context, marked by the success of the neoliberal political economic agenda and the fall of the Soviet bloc. These academic fields emerged to account for the multi-polarization of the world and the rise of non-state actors on the international scene. The concept of transnational relations was tailored in a critical perspective of the realist paradigm of International Relations ${ }^{2}$ (Keohane and Nye 1972). In this perspective, diasporic groups were identified, along with multinational corporations and nonprofit organizations, as actors responsible for the growing complexity of World Politics (Keohane and Nye 1972, 19). In addition, transnationalism and diaspora studies and global studies share a range of assumptions. Chief among them is the idea that the technological revolution and the ensuing "time-space" compression have changed the rules of the social game. Finally, they point to the importance of local identities as an inherent aspect of globalization. In this regard, globalization thinkers such as Luhman, Beck, Giddens, or Castells have criticized the idea of a world as a unified "McWorld." In their works, globalization is depicted as polycentric rather than a-centric (Laïdi 2007).

The state-centered and global paradigms continue to exert a strong influence on migration scholarship. Rather than two opposite external boundaries delimiting the epistemological territory of post-migration studies, it would be fairer to depict them as two forcefields polarizing the academic debate. If the global paradigm has been dominant in the 1990s and early 2000s, there now seems to be a move toward a greater (re)consideration of the role of state actors. 


\section{2. Methodological Innovations}

The last terrain on which the encounter between Diaspora and Transnational Studies has occurred is the one of methodology. A body of innovative methodologies delineates what could be called a "methodological glocalism" as opposed to the "methodological nationalism" and "methodological cosmopolitanism" that characterize alternative approaches to social phenomena. Students of cross-border practices have developed a multipurpose tool-kit likely to overcome the challenges posed by the nature of the research object. The first of these challenges is the multiscalar dimension of migration processes. They span several local settings scattered over the world. Migrants interfere with authorities and existing arrangements at the local, national, or even regional levels. The difficulty is to render the interrelations between processes happening at each of these levels. The second challenge is induced by the scarcity of statistics on "glocal" processes. The measure of flows and the intersection between local and cross-border processes are two key features poorly appraised by existing data. For this reason, students of transnational and diasporic entities have, for long, relied almost exclusively on ethnographic research. The Simultaneous Matched Sample (SMS) methodology elaborated by Valentina Mazzucato (chapter 11) exemplifies the sophistication of multisited ethnography at its best. This approach is based on the parallel and nearly simultaneous investigations of migrant and origin communities by two different research teams. Migrants and their relatives in the place of origin are interviewed on a monthly basis over a year. This provides the possibility of observing the immediate causes and consequences of migrant behaviors in both origin and destination communities. The merit of this approach over classic multisited ethnography is to grasp the simultaneity of cross-border processes. In doing so, the SMS methodology implicitly refers to globalization as a time-space 
compression of social affairs. In addition, the SMS enables the investigators to collect a fair amount of information that enables researchers to envisage quantitative extrapolations. The third interest of the approach is to grant an equal attention to events in sending and receiving areas. Although transnational scholars generally acknowledge the importance of multisited investigations, most research nevertheless presents a bias toward the receiving context. Finally, beyond its technical aspect, the SMS methodology must demonstrate its practical added value compared to classical approaches. The author argues in favor of this added value by listing findings that, it is argued, are more adequately addressed by this approach. Among them stand the transformation of the behavior of migrants over time, the behavior and discourses of migrants during holidays in the place of origin, and the relations between internal and international migration.

I must admit that I have not found these arguments fully convincing. The findings listed in the chapter could have probably been carved out by a committed $\mathrm{PhD}$ student following a sample of migrants and spending a reasonably long period in sending areas. My second reservation is that the SMS methodology is dependent on the willingness of migrants to let researchers interact with their family back home. This is not always the case, especially in areas where the political context remains sensitive. Ultimately the choice of the SMS methodology depends on the willingness to accept the drawbacks of team work for the prospect of getting improved data. This choice must be balanced with the personal sensitivity of researchers, the quality of scientific partnerships in the case study country, and the difficulty of undertaking individual research in sending areas. The SMS approach certainly does not mark the end of individual ethnographic research, but its success is illustrative of the importance of multisited 
methodologies and quantitative/qualitative mixed methods in the "methodologically glocal" toolkit of both transnational and diaspora studies.

The lack of available data on post-migratory cross-border processes such as the density of associational or entrepreneurial partnerships, of long-distance family ties, of political debates and cultural events is partly circumvented by the recourse to network and Web analysis. The study of migrant associations in Spain undertaken by Laura Morales (chapter 14) within the framework of the LOCALMULTIMODEM ${ }^{3}$ program is based on the detailed analysis of the spatial distribution of organizational networks in and outside the host country. A similar approach to the study of migrant associations has been carried out through the European research program TRAMO. ${ }^{4}$ Other studies have developed the analysis of Internet Web sites; their content and interconnections are increasingly used to map virtual diasporas. The chapter of Kissau and Hunger (chapter 13) on the Russian, Kurdish, and Turkish diasporas gives an example of this flourishing strand of research (see also Kuah-Pearce 2008; Berthomière and Hassan 2009). It shows how different diaspora groups use Internet tools in innovative ways that reflect their positioning and structuring between the host and origin countries. Finally, Koen Jonkers (chapter 12) uses another untapped material resource, publication databases, in order to track transnational academic collaborations. The author highlights the extent, directions, and forms of academic partnerships between Chinese and overseas scholars. Thanks to this approach, he challenges the notion of brain drain, showing that highly skilled expatriates interact to a relatively high degree with their former home system.

\section{Divergence: Old Debates, New Perspectives}


This reading of Diaspora and Transnationalism reveals a shift in the debate between transnational and diaspora scholars. In addition to the long-standing opposition between social constructionist (here represented by Glick Schiller) and positivist (Dahinden, Bruneau) approaches to diasporas, a new perspective has emerged. In effect, the multiplication of diaspora policies has made credible a neorealist interpretation of the emergence of diaspora groups (Bauböck). The realist paradigm of International Relations posits the state as the exclusive actor on the international scene. From the seventies onward, this paradigm has been harshly criticized by theorists pointing the growing importance of non-state actors pursuing their own international agenda (Keohane and Nye 1972). The collapse the Soviet Union in the late eighties was perceived as opening an era of turbulence (Rosenau 1990) characterized by the surge of non-state actors challenging the nation-state hegemony. Since the early 2000s, a growing number of scholars have attempted to reassess the role of the state within the globalization process. I here name this scholarly tendency neorealism. Against this backdrop, a growing body of works shows how the formation of a diasporic identity is the product of performative effects of policy makers' and civil society actors' actions and discourses. In the late 1990s, the issue of diasporic policy was a minor concern in the scholarship (Cohen and Vertovec 1999). In contrast, it occupies over a quarter of Diaspora and Transnationalism. Three chapters $(4,7$, and 8$)$ address the topic through different angles while the concluding chapter seeks to incorporate these findings into a wider theoretical framework on diaspora formation. Interestingly, this new line does not divide diaspora and transnational experts but seems to traverse both academic fields. The section below presents successively the three distinct conceptions that polarize current academic debates. 


\subsection{Transnational Social Fields: A Social Constructionist Perspective on Transnationalism and Diaspora}

As mentioned in the introduction, the authors of Diaspora and Transnationalism generally second the idea that diaspora tends to be a specific category of transnational formation. There is, however, an exception that challenges this line of thought. Nina Glick Schiller presents a conceptual framework called "the global power perspective," which, while heavily relying on the concept of transnational social field, dismisses the identity-focused concepts of diaspora and transnational community. The author defines transnational social field as follows: "Transnational social fields are networks of networks that link individuals directly or indirectly to institutions located in more than one Nation-State. These linkages are part of the power dynamics through which institutionalized social relations delineate social spaces" (112). Alongside states, a number of institutions affect the structuration of migratory social fields. These are financial conglomerates, NGOs, religious organizations, treaty-based organizations, and corporations. This approach highlights the structuring power of these global institutions and the variety of strategies adopted by migrants to respond to it.

According to the author, students of transnational community and diaspora tend to focus on identity formation and reproduction strategies:

"[...] scholars of transnational migration and diaspora have often bound their unit of analysis of study along the line of national or ethnic identities. They have generally failed to link their description of migrant local and trans-border connections to analyses of new flexible modes of capital accumulation and the 
contemporary neo-liberal restructuring of space, self and modes of legitimation" (111).

The study of transnational social fields, she argues, has a stronger theoretical purchase insofar as it displaces the focus from identity to agency, highlighting the bearing of state (and non-state actors') policies on cross-border dynamics. By focusing on the diversity of linkages that migrants maintain with other migrant and non-migrant groups, this approach is more likely to unveil the intertwining between state policies, symbolic hegemonies, and migrant strategies. It is worth noting that Glick Schiller's essay in this volume, unlike Thomas Faist's, draws a nuanced parallelism between migration and globalization studies. Although she acknowledges that the world system and other Braudelian world-scale theories maintain an unjustified distinction between global and local level processes (113-4), she summons authors such as Ulrich Beck or Manuel Castells to support her critique of methodological nationalism and other identity-focused approaches. Her social constructionist approach is therefore firmly related to the paradigm of globalization. The author links transnational processes to the neoliberal re-configuration of the world order in which capitalist forces have constrained states' capacities but have given more space to individual people's agency.

\subsection{From Transnational to Diaspora Formations: Unraveling the Spatial/Identity Condition of Migrants}

The two first conceptual chapters of Diaspora and Transnationalism present two ways of posing the problem of the difference between transnational groups and diasporas. Michel Bruneau and Janine Dahinden see the origin of the formal distinction in long-term identity processes at the local and multinational levels. According to them, transnationalism and diaspora 
formations are two ways of overcoming a tension between identity and spatiality inherent to the condition of migrancy. Dahinden argues that a continuum links diaspora and transnational groupings. Diaspora groups (called "localized diasporic transnational formations" (sic)) are firmly anchored in the settlement countries and maintain little more than a shared subjectivity with the origin society or other parts of the diaspora. At the other end of the spectrum, transnationally mobile communities are weakly embedded in the society of arrival but are engaged into constant cross-border practices and circulation. Half way between these two archetypes stands a range of "localized and mobile transnational formations" that entertain a good level of incorporation in the place of arrival while sustaining more or less dense back-andforth movements. According to the author, the passage from one social configuration to the other is explained by integration and the legal context. The emergence of diasporas is the result of a shrinking of migrant spatiality offset by sustained efforts to preserve a shared identity. Compared to transnational communities, diasporas represent a step toward integration. But Janine Dahinden also acknowledges the role of legal restrictions to immigration and to the duration of stay in the destination country and the subsequent agency of migrants who strive to cope with these constrains. Precarious legal statuses tend to force contemporary migrants to limit their stay and remain transnationally mobile. In the most extreme cases of agency deprivation (for refugees or undocumented people), circulation is not an option anymore. This category of people, called the transnational outsiders by the author, tends to privilege localized invisibility. She, however, does not dismiss the relative importance of identity processes in the formation of actual cross-border communities. Paul Boccagni's chapter on Ecuadorians in Italy documents the case of a "localized diaspora transnational formation" in the making. He highlights how, in absence of regular visits paid to the place of origin, long-distance ties sustained between the transnational 
household and relatives in the original home nurture a sense of continued belonging to the origin country.

Although adopting a similar point of departure, Michel Bruneau's analysis follows an opposite direction. A geographer, Bruneau sees in the formation of diasporas primarily a process of several multi-polarizations: first a spatial stratification that emerges as the different poles of the expatriate community in various countries of settlement get increasingly interconnected; then an identity polarization that develops as the gradual embedding into the receiving areas brings about a process of hybridization. At the same time, the common engagement in a set of practices strengthens a shared subjectivity between diaspora members. Diaspora groups, as Rogers Brubaker (2005) has argued elsewhere, can therefore be distinguished according to the "category of practice" that underpins the production of "groupness." Bruneau differentiates commercial, political, and racial/cultural diasporas. This process is often mediated by the territorial embedding of community buildings and areas. Places of worship, shopping areas, community centers, monuments, museums foster the sense of belonging to the same social entity. In contrast to diasporas, transnational groups are characterized by the duality of their identity and the bipolarity of their circulation between the host and source countries. Contrary to Dahinden, Michel Bruneau sees diasporas as a step away from assimilation. Diasporic groups are the result of a deployment of both their shared sense of belonging and practices at a scale beyond the compound formed by arrival and origin settings. The work of Karsten Paerregard on the Peruvian diaspora complements this analysis by focusing on the class behaviors within the same group. The author shows that only the upper class has developed truly diasporic strategies. The Peruvian mestizos have established networks between the different parts of the diaspora in North and Latina America as well as in Europe. These actors display a stronger sense of belonging to 
the same group than working-class migrants. The mobilization of the latter group is restricted to a translocal arena encompassing the places of arrival and origin. The formation of diaspora groups, he concludes, is facilitated by higher social, political, and financial capitals obtained through incorporation.

Beyond their opposite line of thought, Bruneau and Dahinden adopt a definition of transnationalism and diaspora as two related but distinct realities. Both share the view that the difference is a consequence of temporal and spatial processes. Transnational groups become diasporas in the wake of a long-term integration process into local settings and of a transformation of their cross-border embedding. This approach differs from the neorealists' insofar as it posits the emergence of diaspora groups as the consequence of autonomous processes of social differentiation and not, as will be shown below, on the intervention of political actors. This stance, as opposed to the social constructionism of Glick Schiller, can be regarded as positivist insofar as it conceives a positive existence of diaspora and transnational groups, each of them characterized by a set of specific features such as mobility patterns and group consciousness. In a sense, this approach contradicts the idea of globalization as a timespace compression. Time and space continue to matter, even for supranational-scale phenomena. The authors depart from the globalization paradigm. Both draw a perspective on cross-border phenomena equidistant from methodological nationalism and cosmopolitanism.

\subsection{Diaspora and Transnational Groups: A Neorealist Perspective}

Away from the constructionist stance of Nina Glick Schiller and the positivist idea of autonomous production, Rainer Bauböck argues that transnationalism and diasporas are social 
formations produced by contingent factors. Bauböck sees transnationalism as an outcome of the multiplication of citizenship statuses at the local, national, and international levels. The transnational character of migration is favored by the growing varieties of dual citizenship, denizenship, and an array of short-term immigration statuses. Transnationalism is therefore the consequence of the evolution of migration regimes. Migrants' mobility is the response of the growing precariousness of migration statuses. When possible, migrants opt for dual citizenship in order to preserve their freedom of circulation in a context of border closing. In contrast, diasporas are transnational communities organized and mobilized by political actors. Group consciousness forms along the lines of hegemonic narratives of belonging. Narratives of states and diasporic civil society actors tailor diasporic imaginings that fit into utilitarian and political objectives. As mentioned earlier, sending states rely on diasporic sentiments to enhance remittances and investments of expatriates. But diaspora mobilization can also serve to support homeland political interests and lobby the governments of receiving countries. Agnieszka Weinar, Myra Waterbury, and Maria Koinova (chapters 4, 7, and 8) give ample illustration of this. The narratives conveyed by civil society actors are not necessarily less hegemonic than the ones proposed by states. As put forward by Koinova (chapter 8), despite the promotion of democratic and pluralist values that often underpins their objectives, civil society actors tend to disregard cultural, gender, or political diversity, both within the diaspora and the homeland. Bauböck and other authors following the same line of thought remain mute on the structural consequences that these discourses have on the morphology of transnational groups. Even when he acknowledges the spatial and identity distinctiveness of diaspora groups, Bauböck argues that they are explenanda (factors to be explained) rather than explenandum (causal factors). 
Bauböck, in line with Bruneau and Dahinden, argues that transnational groups and diasporas present distinct features. However, for him, transnationalism and diaspora formation are spurred by contingent factors (the mutation of migration and citizenship regimes on the one hand, political strategies of states and civil society actors on the other) rather than by social dynamics of integration and cross-border embedding. These phenomena are less the responses to an identity/space conundrum than to the mutation of state and politics in the context of globalization (155).

\section{Conclusion: Diaspora and Transnationalism as Social Constructs}

Diaspora and Transnationalism brings to the fore new lines of division along which the current scholarly debate on migrant social formations (increasingly infused with non-academic considerations) is taking place. Next to the positivist conception of transnationalism and diaspora and its constructionist critique, a new school of thought argues that diasporas are less an outcome of intertwined identity processes and cross-border practices than of an evolution of legal and political opportunity structures. The supporters of this conception focus on the formulation and implementation of diasporic policies and agendas by a range of actors: international organizations, volunteer organizations, NGOs, governments of receiving and origin countries, and so forth.

At the fringes of academic and policy spheres, a new strand of works moves away from the aforementioned theoretical considerations. A growing number of experts see transnationalism and diaspora as two facets of the same cross-border coin. In this respect, diaspora is the name 
given to any group of expatriate financial remitters to their place of origin. This highly ascriptive definition of diaspora pays little attention to the social morphology and internal diversity of migrant social formations. Does this perspective mark the obsolescence of the concept of diaspora? The dangers of the gradual widening of its definition have already been pointed out (Brubaker 2005), but recurrent calls to stick to a more restrictive definition have fallen short in the face of the contagious influence of policy-oriented research. This trend could rapidly lead to its abandonment in the social sciences literature. In this context, the cross-fertilizing fields of transnational and diaspora studies may open an avenue to stimulate conceptual innovations. By mapping the current debates, Diaspora and Transnationalism implicitly highlights the gaps that impede the emergence of an overarching framework of analysis. One striking absence of this book is any chapter proposing an empirical description of the evolution of a group from a transnational to a diasporic form. The diachronic comparison of the same migrant groups over at least two periods of their history would shed light on the emergence of new characteristics and the demise of others. Such an approach would highlight either the shrinking (Janine Dahinden) or the enlargement (Michel Bruneau) of cross-border ties paralleling the emergence of diasporic identities. The use of archive analysis (of public or civil society organizations) and oral history are methods insufficiently used by students of migration. In addition, the different chapters of the book display a clear-cut disconnection between studies of macro-level politics and micro-level social dynamics. For this reason, I fully second Thomas Faist's call (13) for a more integrated approach to social structures and migrants' agency. Finally, as shown in this article, there is in the social sciences a growing account of the influence of the legal and policy contexts in the formation of cross-border social entities. But more remains to be done on the influence of nonpolitical factors such as the de-structuration of community agrarian systems, of the 
reconfiguration of patriarchal systems and, more generally, of the surge of individualism in departure areas. Addressing such an issue would lead scholars not only to revisit existing common approaches to cross-border phenomena but also the broader architecture of migration studies, so far strongly polarized between analyses of development and integration (Glick Schiller and Faist 2010). We can hope that Diaspora and Transnationalism will contribute to a surge of combined analysis of societal and transnational processes.

\section{Notes}

1. The term glocalization was popularized by Robertson (1992, 173-4) to describe how global pressures and demands are made to conform to local conditions. Here, the global is modified by its contact with the local. Thus, there is no homogenizing force at work here but rather new and various possibilities for fusion and creativity (Cohen and Kennedy 2007).

2. This paradigm is posited on the idea that nation-states pursuing their particular interests are the exclusive actors on the international arena.

3. Multicultural Democracy and Immigrants' Social Capital in Europe: Participation, Organisational Networks and Public Policies at the Local Level (LOCALMULTIMODEM). The Spanish program was funded by the Spanish Ministry of Science and Education and by the Seneca Foundation of the Region of Murcia. See www.um.es/capsocinmig. accessed 20/02/2013.

4. Diffusion and Context of Transnational Migrant Organizations in Western Europe (TRAMO). The Program was funded by the Volkswagen Foundation. The study group includes the Department of Sociology of the University of Bochum (coord.), the University of Granada, the International Migration Institute of Oxford University and the University of Warsaw accessed 20/02/2013 2001, http://www.ruhr-uni-bochum.de/tramo/en/index.shtml.

\section{References}

<edb>Berthomière, William, and Souley Hassan. 2009. "Les Diasporas: Communautés Globales de l'Ere Digitale."

In L'enjeu mondial, edited by C. Jaffrelot, 227-35. Paris: CERI/L'Express.</edb>

<jrn>Brubaker, Rogers. 2005. “The ‘Diaspora’ Diaspora.” Ethnic and Racial Studies 28 (1): 1-19. http://dx.doi.org/10.1080/0141987042000289997.</jrn> 
$<$ bok>Cohen, Robin, and Paul Kennedy. 2007. Global Sociology. Basingstoke: Palgrave Macmillan.</bok>

<edb>Cohen, Robin, and Steven Vertovec, eds. 1999. Migration, Diasporas and Transnationalism. Cheltenham:

Edward Elgar. $</$ edb $>$

$<$ edb $>$ Glick Schiller, Nina, and Thomas Faist, eds. 2010. Migration, Development and Transnationalization: A

Critical Stance., New York: Berghahn Books. $</$ edb $>$

<other>Kapur, Devesh. 2004. "Remittances: The New Development Mantra?" G-24 Discussion Papers. New York:

United Nations. </other>

$<$ bok>Keohane, Robert, and Joseph Nye. 1972. Transnational Relations and World Politics. Cambridge, MA:

Harvard University Press. $</$ bok $>$

$<\mathrm{edb}>$ Kuah-Pearce, Kuhn Eng, ed. 2008. Chinese Women and Cyberspace. Amsterdam: Amsterdam University

Press. http://dx.doi.org/10.5117/9789053567517</edb $>$

$<$ bok>Laïdi, Zaki. 2007. The Great Disruption. Cambridge: Polity Press. $<$ /bok>

$<$ jrn>Levitt, Peggy, and Nina Glick Schiller. 2004. “Conceptualizing Simultaneity: A Transnational Social Field

Perspective on Society." International Migration Review 38 (3): 1002-39. http://dx.doi.org/10.1111/j.1747-

7379.2004.tb00227.x. $</ \mathrm{jrn}>$

$<$ bok>Robertson, Roland. 1992. Globalization: Social Theory and Global Culture. London: Sage.</bok>

$<$ bok $>$ Rosenau, James. 1990. Turbulence in World Politics. Princeton, NJ: Princeton University Press. $</$ bok $>$

$<$ bok>Soysal, Yasemin. Nuhoglu. 1994. Limits of Citizenship. Migrants and Postnational Membership in Europe.

Chicago: University of Chicago Press. $<$ /bok $>$

$<$ bok $>$ Touraine, Alain. 2007. Penser autrement. Paris: Fayard. $<$ /bok $>$ 
Journal: DIASPORA; Volume 16; Issue: 3

DOI: $10.3138 /$

$<$ other>Van Hear, N., S. Vertovec, and F. Pieke, eds. 2004. The Contribution of UK-based Diasporas to Development and Poverty Reduction. Report by the ESRC Centre on Migration, Policy and Society (COMPAS), University of Oxford for the Department for International Development. Oxford: 45.</other> $<$ jrn>Wimmer, Andreas, and Nina Glick Schiller. 2003. "Methodological Nationalism, the Social Sciences and the Study of Migration: An Essay in Historical Epistemology.” International Migration Review 37 (3): 576610. http://dx.doi.org/10.1111/j.1747-7379.2003.tb00151.x. $</$ jrn $>$ 